\title{
Analisis Kerusakan dan Perbaikan Jalan Beraspal pada Lapisan Asphalt Concrete-Wearing Course (AC-WC) di Kota Surabaya
}

\author{
Analysis on Damage and Repair of Asphalt Concrete Roads in Asphalt Concrete-Wearing Course (AC- \\ WC) in Surabaya City
}

\author{
Rindi Sekar Andika ${ }^{1^{*}}$, Ari Widayanti ${ }^{2}$ \\ ${ }^{1,2}$ Program Studi Transportasi, Program Vokasi, Universitas Negeri Surabaya
}

\begin{tabular}{l}
\hline ARTICLE INFO \\
\hline Article history: \\
DOI: \\
10.30595/pspfs.v1i.149 \\
Submitted: \\
June 28, 2021 \\
Accepted: \\
July 10, 2021 \\
Published: \\
Oct 31, 2021 \\
\hline
\end{tabular}

Keywords:

Road Damage, PCI Method, Maintenance, Repair

\begin{abstract}
AC-WC asphalt layer is a surface layer of flexible pavement construction that bears a direct load from the vehicle wheels. The increase in the number and load of traffic that occurs every year impacts road conditions and can cause damage. This requires analysis, repair and maintenance of roads for roads to function properly. The purpose of this study was to analyze road damage and provide alternative treatments for each road based on the type and level of damage that occurs. The method used was literature study, observation, documentation, and analysis with the PCI method. Observations were made on roads with class III flexible pavement in South Surabaya City. The results obtained were that the most dominant type of damage was crack damage, the level of road damage varies (low, medium, high severity) and there were different types of damage at the same point. The highest percentage and value of the damage were on Kembang Kuning Road and Pakis Tirtosari III Road. Based on the PCI method, the condition value of Dukuh Kupang XX Road was the lowest, at 25 (very poor). On Kembang Kuning Road and Pakis Tirtosari III Road maintenance work was needed, while Dukuh Kupang Road required road repairs.
\end{abstract}

This work is licensed under a Creative Commons Attribution 4.0 International License.

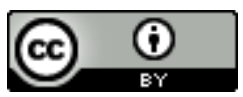

\author{
Corresponding Author: \\ Rindi Sekar Andika \\ Program Studi Transportasi, Program Vokasi, Universitas Negeri Surabaya \\ Jalan Ketintang, Surabaya \\ Email: rindi.18010@mhs.unesa.ac.id
}

\section{PENDAHULUAN}

Jalan adalah salah satu aset prasarana perhubungan darat yang mendukung mobilitas masyarakat dari satu tempat ke tempat lainnya, sehingga perkembangan suatu daerah bergantung pada kondisi jalan. Berdasarkan UU RI No 38 Tahun 2004, tentang jalan. Jalan merupakan prasarana transportasi yang memiliki peran dalam bidang ekonomi, sosial budaya, lingkungan hidup, politik, pertahanan, dan keamanan untuk digunakan sebagai kemakmuran masyarakat. Jalan dibagi atas beberapa pengelompokan, yaitu berdasarkan sistem, fungsi, status, muatan sumbu, dan penyediaan prasarana jalan. Perkerasan Lentur (Flexible Pavement), terdiri atas lapisan tanah dasar (base), lapisan pondasi bawah (subbase), lapis pondasi atas (base), dan lapisan permukaan (surface course). Penyebab kerusakan jalan, secara umum yaitu: umur rencana jalan terlewati, genangan air pada permukaan jalan yang tidak dapat mengalir akibat drainase yang kurang berfungsi, kelebihan berat kendaraan yang dapat menyebabkan umur pakai jalan yang semakin pendek dari umur rencana, perencanaan dan pengawasan yang kurang tepat (Widayanti dkk, 2020).

Secara umum kerusakan timbul, tidak disebabkan oleh satu faktor saja. Terdapat banyak selain faktor yang merupakan gabungan dari penyebab kerusakan, contoh adalah retak pinggir yang memungkinkan air merusak lapisan dengan meresap, yang berakibat melemahkan daya dukung lapisan dibawahnya (Departemen Pekerjaan Umum, 2007). Model dari kinerja sebuah perkerasan selalu mempertimbangkan interaksi dinamis antara kendaraan dan 
perkerasan. Beban dinamis tambahan akibat interaksi kendaraan-jalan ditemukan memiliki dampak yang signifikan pada kerusakan perkerasan dalam hal rutting dan retakan kelelahan dan dampak yang lebih kecil pada kinerja fungsional perkerasan (Misagi dkk, 2021). Pekerjaan pemeliharaan yang dilakukan dengan baik, maka dapat menjaga jalan agar tidak rusak, sehingga pengguna jalan akan memiliki kenyamanan pada saat mengendarai kendaraan, sebaliknya jika pemeliharaan tidak dilakukan dengan baik, maka dapat mengakibatkan jalan cepat rusak dan biaya perbaikan akan semakin mahal (Japan International Cooperation Agency, 2005).

Konsep dari perkerasan lentur, yaitu dengan menghamparkan beberapa lapisan permukaan dan lapisan pondasi dengan lapisan lainnya, diantara lapisan permukaan dan pondasi. Hal ini bertujuan untuk dapat mengendalikan regangan pada tanah dasar, serta mencegah defleksi permanen, kekuatan dari perkerasan lentur dari ketebalan pada setiap lapisan (Hardiyatmo, 2015). Jenis kerusakan perkerasan lentur terdapat beberapa jenis, yaitu: deformasi, retak, kerusakan tekstur permukaan, lubang, tambalan, persilangan rel, dan kerusakan di tepi perkerasan. Terdapat 3 tingkatan pada kerusakan perkerasan, yaitu: low, medium, dan high severity (Hardiyatmo, 2015). Metode PCI (Pavement Condition Index) merupakan metode untuk menentukan nilai kondisi dan penanganan kerusakan perkerasan jalan.

Kota Surabaya merupakan kota tersibuk setelah kota Jakarta, oleh karena itu, banyak aktivitas masyarakat, industri dan perdagangan yang mengakibatkan peningkatan jumlah dan beban lalu lintas setiap tahun. Perkerasan lentur umumnya banyak dijumpai pada jalan di Kota Surabaya, secara khusus di wilayah Surabaya Selatan. Lapisan AC-WC (Asphalt Course - Wearing Course) merupakan lapisan permukaan pada perkerasan lentur yang menahan beban langsung dari roda kendaraaan. Seiring dengan berjalannya waktu, peningkatan jumlah dan beban lalu lintas kendaraan akan mengakibatkan kerusakan yang mempengaruhi kualitas pelayanan jalan, seperti kemacetan atau kecelakaan lalu lintas yang dapat mengganggu kenyamanan pengguna jalan. Adanya kerusakan jalan membutuhkan pemeliharaan dan perbaikan jalan untuk mengembalikan jalan agar dapat melayani pengguna jalan secara baik.

Berdasarkan uraian di atas, maka tujuan studi ini adalah untuk mengetahui jenis dan tingkat kerusakan jalan, persentase dari setiap kerusakan, nilai kondisi kerusakan perkerasan lentur dengan metode PCI (Pavement Condition Index) pada jalan aspal di kota Surabaya bagian Selatan. Berdasarkan analisis kerusakan jalan tersebut diharapkan dapat menghasilkan alternatif perbaikan dan pemeliharaan yang efektif pada jalan beraspal di kota Surabaya bagian Selatan.

\section{METODE PENELITIAN}

Lokasi studi pada 11 jalan kota Surabaya bagian Selatan. Tahapan dimulai dengan melakukan studi pustaka untuk memperoleh referensi jurnal maupun buku dengan topik terkait. Metode observasi dilakukan dengan pengamatan langsung dan mengambil dokumentasi pada 11 jalan perkerasan lentur di Kota Surabaya Selatan. Metode dokumentasi dengan mengumpulkan data dari hasil observasi dan membandingkan hasil observasi dengan data dari jurnal maupun buku terkait.

Indeks kondisi perkerasan adalah metode tipe objektif untuk mengevaluasi perkerasan jalan secara visual, yang mempertimbangkan tingkat dan keparahan cacat yang ditemukan di lokasi studi tertentu (Pinatt dkk, 2020). Nilai PCI didasarkan pada skor nilai deduksi kumulatif pada jenis, jumlah, dan tingkat kesusahan serta jenis perkerasan jalan. Evaluasi fungsional perkerasan jalan terdiri dari kumpulan data jalan yang berkaitan dengan tingkat keparahan dan luas permukaan kerusakan (Shah, 2013).

Tabel 1. Nilai PCI dan Nilai Kondisi

\begin{tabular}{ll}
\hline \multicolumn{1}{c}{ Nilai PCI } & \multicolumn{1}{c}{ Kondisi } \\
\hline $0-10$ & Gagal (Failed) \\
$11-25$ & Sangat Buruk (Very Poor) \\
$26-40$ & Buruk (Poor) \\
$41-55$ & Sedang (Fair) \\
$56-70$ & Baik (Good) \\
$71-85$ & Sangat Baik (Very Good) \\
$86-100$ & Sempurna (Excellent) \\
\hline
\end{tabular}

Sumber: FAA, 1982; Shanin 1994 dalam Hardiyatmo, 2015

\section{HASIL DAN PEMBAHASAN}

\section{Hasil Observasi Jenis dan Tingkat Kerusakan pada 11 Jalan di Kota Surabaya Bagian Selatan}

Kondisi jalan di wilayah Surabaya Selatan sebagian besar merupakan konstruksi perkerasan lentur. Observasi dilakukan pada 11 jalan sebagai sampel acak dengan klasifikasi jalan kelas IIIC, pada setiap jenis dan tingkat kerusakan jalan. Jalan Pakis sepanjang 650 m, memiliki kerusakan mengembang tingkat high, amblas tingkat high, Lubang tingkat medium, dan alur tingkat medium. Jalan Kembang Kuning sepanjang 450 m, memiliki kerusakan retak buaya tingat low dan pengausan tingkat medium. Jalan Kanwa sepanjang 200 m, memiliki kerusakan bergelombang tingkat medium, pengelupasan tingkat high, dan lubang tingkat high. 
Jalan Hamzah Fansyuri sepanjang 270 m, memiliki kerusakan lubang tingkat high. Jalan Pakis Tirtosari sepanjang $850 \mathrm{~m}$, memiliki kerusakan pelapukan dan butiran lepas tingkat low, retak memanjang tingkat low, retak kulit buaya tingkat high, sungkur tingkat medium dan retak berkelok-kelok tingkat low. Jalan Pakis Tirtosari I sepanjang $200 \mathrm{~m}$, memiliki kerusakan retak berkelok-kelok tingkat low dan retak memanjang tingkat low. Jalan Pakis Tirtosari III sepanjang $450 \mathrm{~m}$, memiliki kerusakan retak memanjang tingkay high, pengelupasan tingkat medium, bergelombang tingkat medium, dan retak kulit buaya tingkat low dan medium. Jalan Bintang Diponggo sepanjang 240 $\mathrm{m}$, memiliki kerusakan retak berkelok-kelok tingkat low, tambalan tingkat medium, alur tingkat medium, dan pengelupasan tingkat low.

Jalan Dukuh Kupang Timur I sepanjang 400 m, dengan kerusakan retak melintang tingkat medium, retak kulit buaya tingkat medium, dan tambalan tingkat low. Jalan Dukuh Kupang Timur X sepanjang 450 m, dengan kerusakan amblas tingkat high, pelapukan dan butiran lepas tingkat medium, dan pengelupasan tingkat high, dan tambalan tingkat medium. Jalan Dukuh Kupang XX sepanjang 550 m, dengan kerusakan retak melintang tingkat low, alur tingkat high, pelapukan dan butiran lepas tingkat high, dan lubang tingkat medium.

Persentase kerusakan ditentukan dengan menghitung nilai kerusakan dari angka 1-10 yang didasarkan dari pengamatan langsung, berdasarkan tingkatannya dengan nilai 1-5 pada tingkat low, nilai 6-9 tingkat medium, dan nilai 10 tingkat high. Hasil nilai setiap jenis kerusakan dibagi nilai keseluruhan dan dikali 100, maka didapatkan persentase setiap jenis kerusakan. Jalan Pakis memiliki persentase tertinggi, sedangkan nilai tertinggi didapatkan pada jalan Kembang Kuning.

\section{Jenis dan Tingkat Kerusakan pada 11 Jalan di Kota Surabaya Bagian Selatan}

Metode PCI digunakan untuk menentukan nilai kondisi setiap jalan dan menentukan prioritas penanganannya. Berikut ini contoh penyelesaian metode PCI pada jalan yang telah diobservasi, yaitu:

1. Kondisi Kerusakan pada Jalan Pakis Tirtosari

Data dari setiap kerusakan perkerasan lentur pada Jalan Pakis Tirtosari I disusun pada Tabel 2, dan dilengkapi dengan jenis, jumlah, persentase, ukuran serta tingkat kerusakan yang terjadi.

Tabel 2. Kondisi Kerusakan pada Jalan Pakis Tirtosari I

\begin{tabular}{|c|c|c|c|c|c|c|c|c|c|c|}
\hline \multirow[t]{2}{*}{ No. } & \multirow{2}{*}{$\begin{array}{l}\text { Loka } \\
\text { si }\end{array}$} & \multirow{2}{*}{$\begin{array}{c}\text { Panjan } \\
\text { g Jalan } \\
\text { (m) }\end{array}$} & \multirow{2}{*}{$\begin{array}{l}\text { Lebar } \\
\text { Jalan } \\
(\mathbf{m})\end{array}$} & \multirow{2}{*}{$\begin{array}{c}\text { Jenis } \\
\text { Kerusak } \\
\text { an Jalan }\end{array}$} & \multirow{2}{*}{$\begin{array}{c}\text { Jumlah } \\
\text { Kerusak } \\
\text { an }\end{array}$} & \multirow{2}{*}{$\begin{array}{c}\text { Persenta } \\
\text { se } \\
\text { Kerusak } \\
\text { an }(\%)\end{array}$} & \multicolumn{3}{|c|}{ Ukuran } & \multirow{2}{*}{$\begin{array}{c}\text { Tingkat } \\
\text { Kerusakan }\end{array}$} \\
\hline & & & & & & & $\begin{array}{c}\text { Pan } \\
\text { jang } \\
(\mathbf{m})\end{array}$ & $\begin{array}{c}\text { Lebar } \\
\text { (m) }\end{array}$ & $\begin{array}{l}\text { Luas } \\
\left(\mathbf{m}^{2}\right)\end{array}$ & \\
\hline \multirow[t]{11}{*}{1.} & & 200 & 7,5 & Retak & 3 & $50 \%$ & 25,3 & 0,8 & 30,36 & Low \\
\hline & Jalan & & & Berkelok & & & & & & \\
\hline & Pakis & & & - Kelok & & & & & & \\
\hline & Tirtos & & & (Meande & & & & & & \\
\hline & ari I & & & ring) & & & & & & \\
\hline & & & & Retak & 2 & $50 \%$ & 21,4 & 2,1 & 44,94 & Low \\
\hline & & & & $\begin{array}{l}\text { Memanja } \\
\text { ng }\end{array}$ & & & & & & \\
\hline & & & & (Longitu & & & & & & \\
\hline & & & & dinal & & & & & & \\
\hline & & & & Cracks) & & & & & & \\
\hline & & & & Total & 5 & 100 & & & & \\
\hline
\end{tabular}

Berdasarkan pada Tabel 2, maka dilakukan penilaian dengan mencari kerapatan, deduct value, menentukan nilai izin dari deduct value, corrected deduct value, dan nilai PCI. Berikut merupakan penjelasan dari setiap langkah untuk menentukan nilai PCI, yaitu:

1. Kerapatan (Density) pada jalan Pakis Tirtosari I (\%)

Kerapatan dihitung dengan luas kerusakan dibagi dengan luas setiap kerusakan dan luas jalan Pakis Tirtosari I dan dikali 100, dengan hasil berupa persentase, yaitu:

$$
\begin{aligned}
& \text { 1. Kerapatan Retak Berkelok - Kelok (Meandering) }(\%)=\frac{30,36}{1500} x 100=2,02 \% \text {. } \\
& \begin{array}{c}
\text { 2. Kerapatan Retak Memanjang (Longitudinal Cracks) Low }(\%)=\frac{44,94}{1500} x 100 \\
=2,99 \%
\end{array}
\end{aligned}
$$

2. Menghitung nilai pengurangan Deduct Value pada Jalan Pakis Tirtosari I 
Menentukan nilai deduct value menggunakan grafik yang sesuai dengan setiap jenis kerusakan dan tingkat kerusakan. Berikut ini merupakan hasil grafik dari setiap jenis kerusakan, yaitu:

1. Deduct Value Retak Berkelok - Kelok (Meandering)

Berikut gambar 3 grafik untuk menentukan deduct value kerusakan retak berkelok - kelok (transverse cracks).

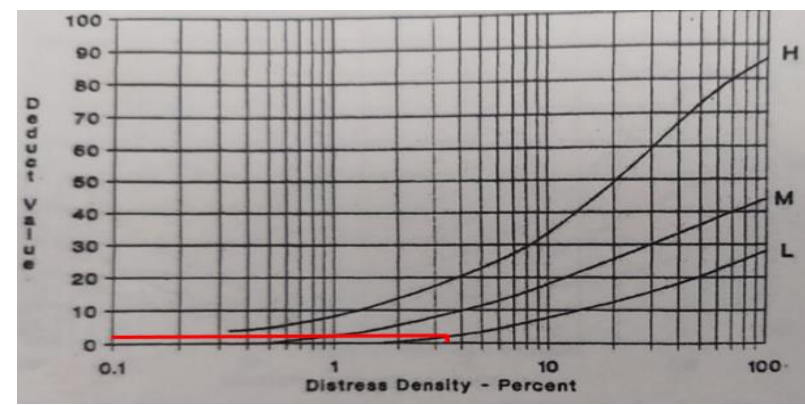

Gambar 1. Plotting Deduct Value Retak Berkelok - Kelok (Meandering) Jalan Pakis Tirtosari I Sumber: Hasil Analisis (2020)

2. Deduct Value Retak Memanjang (Longitudinal Cracks)

Berikut ini adalah Gambar 4 berupa grafik untuk menentukan deduct value kerusakan retak memanjang (longitudinal cracks).

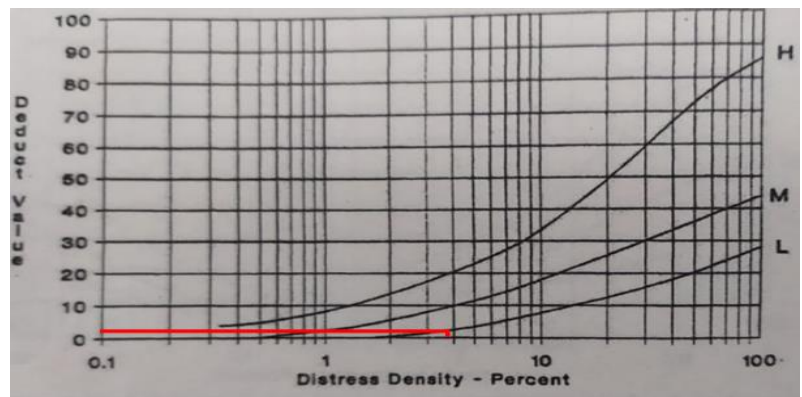

Gambar 2. Plotting Deduct Value Retak Memanjang (Longitudinal Cracks) Jalan Pakis Tirtosari I Sumber: Hasil Analisis (2020)

Maka nilai deduct value kedua kerusakan sama, yaitu sebesar 2. Nilai deduct value terbesar digunakan untuk menentukan nilai izin deduct value.

3. Menentukan Nilai Izin dari Deduct Value Pakis Tirtosari I

Deduct Value Tertinggi didapatkan dari kerusakan lubang sebesar 2, maka dimasukkan ke dalam persamaan dibawah ini:

$$
m=1+\frac{9}{98} x(100-2)=10>2
$$

Hasil yang diperoleh sebesar 10 maka $10>2$ (angka 2 merupakan jumlah data nilai pengurang DV pada Jalan Pakis Tirtosari I).

4. Mencari Corrected Deduct Value (CDV) Jalan Pakis Tirtosari I

Nilai deduct didapatkan dari grafik corrected deduct value. Gambar 5 merupakan grafik corrected deduct value keseluruhan kerusakan, dengan keterangan warna merah untuk kerusakan retak berkelok - kelok (transverse cracks), dan warna biru dongker untuk kerusakan kerusakan retak memanjang (longitudinal cracks). 


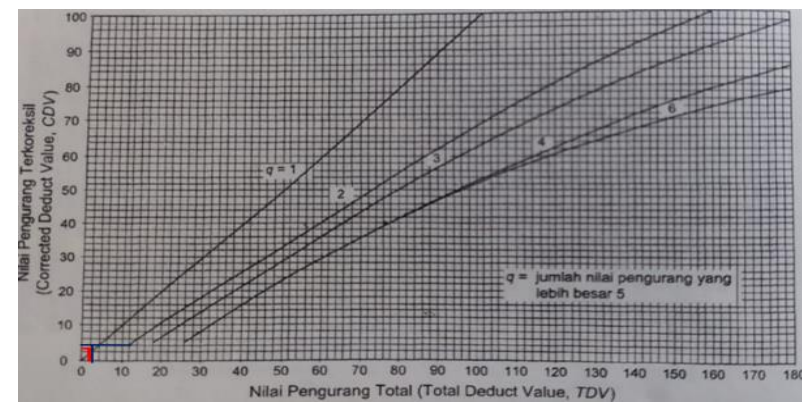

Gambar 3. Plotting Correct Deduct Value Jalan Pakis Tirtosari I

Sumber: Hasil Analisis (2020)

5. Nilai PCI Jalan Pakis Tirtosari I

Penentuan nilai PCI berdasarkan pengurangan CDV. Berikut ini merupakan tabel untuk menentukan nilai PCI jalan Pakis Tirtosari.

Tabel 3 Nilai PCI pada Jalan Pakis Tirtosari I

\begin{tabular}{|c|c|c|c|c|c|c|c|}
\hline Lokasi & $\begin{array}{c}\text { Luas } \\
\text { Jalan } \\
\left(\mathbf{m}^{2}\right)\end{array}$ & $\begin{array}{c}\text { Jenis } \\
\text { Kerusakan } \\
\text { Jalan }\end{array}$ & $\begin{array}{c}\text { Density } \\
(\%)\end{array}$ & $\begin{array}{c}\text { Deduct Value }=\text { Total } \\
\text { Deduct Value }\end{array}$ & $\mathbf{q}$ & $\begin{array}{c}\text { Corrected } \\
\text { Deduct } \\
\text { Value }(\mathrm{CDV})\end{array}$ & $\begin{array}{c}\text { Nilai } \\
\text { PCI } \\
(100- \\
\text { CDV })\end{array}$ \\
\hline $\begin{array}{l}\text { Jalan } \\
\text { Pakis }\end{array}$ & 1500 & $\begin{array}{l}\text { Retak Berkelok } \\
\text { - Kelok }\end{array}$ & 2,02 & 2 & 2 & 2 & 98 \\
\hline $\begin{array}{l}\text { Tirtosari } \\
\text { I }\end{array}$ & & $\begin{array}{c}\text { Retak } \\
\text { Memanjang }\end{array}$ & 2,99 & 2 & 1 & 4 & 96 \\
\hline \multicolumn{7}{|c|}{$\begin{array}{c}\text { Total Nilai PCI } \\
\text { Rata-rata Nilai PCI }\end{array}$} & $\begin{array}{c}194 \\
38\end{array}$ \\
\hline
\end{tabular}

Untuk menentukan nilai PCI satu bagian jalan, maka digunakan persamaan berikut ini:

$$
P C l_{f}=\frac{(5-0)}{5} \times 38+\frac{0}{5} \times 0=38(\text { Buruk })
$$

Hasil nilai PCI pada jalan Pakis Tirtosari I, sebesar 38 yang berarti dalam kondisi buruk (poor), maka diperlukan perbaikan, agar nilai kondisi jalan tidak menurun lagi.

Hasil nilai PCI dan nilai kondisi pada 11 jalan yang telah diobservasi, yaitu: jalan Pakis dengan nilai PCI 44,5 dan kondisi sedang (fair), Jalan Kembang Kuning dengan nilai PCI 46,25 dan kondisi sedang (fair), Jalan Kanwa dengan nilai PCI 29 dan nilai kondisi buruk (poor), Jalan Hamzah Fansyuri dengan nilai PCI 35,5 dan kondisi buruk (poor), Jalan Pakis Tirtosari dengan nilai PCI 41 dan kondisi sedang (fair), Jalan Pakis Tirtosari I dengan nilai 38 dan kondisi buruk (poor), Jalan Pakis Tirtosari III dengan nilai 29,58 dan kondisi buruk (poor), Jalan Bintang Diponggo dengan nilai 44,87 dan kondisi sedang (fair), Jalan Dukuh Kupang Timur I dengan nilai 37,85 dan kondisi buruk (poor), Jalan Dukuh Kupang Timur X dengan nilai 46,62 dan kondisi sedang (fair), Jalan Dukuh Kupang XX dengan nilai 25 dan kondisi sangat buruk (very poor).

Jenis, tingkat kerusakan dan nilai kondisi pada setiap jalan dapat memberikan solusi yang efektif untuk menghasilkan alternatif penetapan perbaikan atau pemeliharaan jalan dirangkum pada Tabel 4 berikut ini.

Tabel 4. Alternatif Perbaikan atau Pemeliharaan

\begin{tabular}{cllcl}
\hline No. & Lokasi & Jenis Kerusakan & $\begin{array}{c}\text { Tingkat } \\
\text { Kerusakan }\end{array}$ & \multicolumn{2}{c}{ Alternatif } \\
\hline $1 . \quad \begin{array}{l}\text { Jalan } \\
\text { Pakis }\end{array}$ & Mengembang & High & $\begin{array}{l}\text { Perbaikan: pada bagian kerusakan yang membentuk } \\
\text { cekungan, makan diberi penambalan pada seluruh } \\
\text { penambalan }\end{array}$ \\
& Amblas & High & $\begin{array}{l}\text { Perbaikan: melakukan perawatan permukaan (surface } \\
\text { treatment) }\end{array}$ \\
& Lubang & Medium & $\begin{array}{l}\text { Perbaikan: melakukan penambalan di seluruh kedalaman } \\
\text { Medium }\end{array}$ & $\begin{array}{l}\text { Perbaikan: melakukan penambalan seluruh kedalaman } \\
\text { atau memberikan lapisan tambahan campuran aspal panas }\end{array}$
\end{tabular}




\begin{tabular}{|c|c|c|c|c|}
\hline No. & Lokasi & Jenis Kerusakan & $\begin{array}{c}\text { Tingkat } \\
\text { Kerusakan }\end{array}$ & Alternatif \\
\hline \multirow[t]{2}{*}{2.} & Jalan & Retak Buaya & Low & Pemeliharaan: belum memerlukan pemeliharaan \\
\hline & $\begin{array}{l}\text { Kembang } \\
\text { Kuning }\end{array}$ & Pengausan & Medium & Perbaikan: memberikan pelapisan ulang (overlay) \\
\hline \multirow[t]{3}{*}{3.} & $\begin{array}{l}\text { Jalan } \\
\text { Kanwa }\end{array}$ & Bergelombang & Medium & $\begin{array}{l}\text { Perbaikan: menutup kerusakan gelombang yang telah } \\
\text { menjadi lubang dengan tambalan }\end{array}$ \\
\hline & & Pengelupasan & High & Perbaikan: memberikan lapisan tambahan (overlay) \\
\hline & & Lubang & High & $\begin{array}{l}\text { Perbaikan: melakukan penambalan pada seluruh } \\
\text { kedalaman lubang }\end{array}$ \\
\hline 4. & $\begin{array}{l}\text { Jalan } \\
\text { Hamzah } \\
\text { Fansyuri }\end{array}$ & Lubang & High & $\begin{array}{l}\text { Perbaikan: melakukan penambalan pada seluruh } \\
\text { kedalaman lubang }\end{array}$ \\
\hline \multirow[t]{6}{*}{5.} & Jalan & Pelapukan dan & Low & Pemeliharaan: belum memerlukan pemeliharaan \\
\hline & Pakis & Butiran Lepas & & \\
\hline & Tirtosari & Retak Memanjang & Low & Pemeliharaan: belum memerlukan pemeliharaan \\
\hline & & $\begin{array}{l}\text { Retak Kulit Buaya } \\
\text { (Alligator Cracks) }\end{array}$ & High & $\begin{array}{l}\text { Perbaikan: melakukan penambalan parsial atau seluruh } \\
\text { kedalaman atau dapat melakukan rekonstruksi pada } \\
\text { perkerasan }\end{array}$ \\
\hline & & Sungkur & Medium & $\begin{array}{l}\text { Perbaikan: jika sungkur dangkal, maka dapat dibongkar } \\
\text { dan diberi lapisan tambahan campuran aspal panas (hot } \\
\text { mix) atau hanya menambal seluruh kedalaman sungkur }\end{array}$ \\
\hline & & $\begin{array}{l}\text { Retak Berkelok - } \\
\text { Kelok }\end{array}$ & Low & $\begin{array}{l}\text { Pemeliharaan: dilakukan penutupan retakan berdasarkan } \\
\text { ukuran tingkat kerusakan aspal }\end{array}$ \\
\hline \multirow[t]{2}{*}{6.} & $\begin{array}{l}\text { Jalan } \\
\text { Pakis }\end{array}$ & $\begin{array}{l}\text { Retak Berkelok - } \\
\text { Kelok }\end{array}$ & Low & $\begin{array}{l}\text { Pemeliharaan: dilakukan penutupan retakan berdasarkan } \\
\text { ukuran tingkat kerusakan aspal }\end{array}$ \\
\hline & Tirtosari I & Retak Memanjang & Low & $\begin{array}{l}\text { Pemeliharaan: melakukan penutup pada retakan yang } \\
\text { mulai mengganggu kondisi jalan }\end{array}$ \\
\hline \multirow[t]{5}{*}{7.} & $\begin{array}{l}\text { Jalan } \\
\text { Pakis }\end{array}$ & Retak Memanjang & High & $\begin{array}{l}\text { Perbaikan: melakukan penambalan jika retakan di ikuti } \\
\text { jenis retak yang lain }\end{array}$ \\
\hline & Tirtosari & Pengelupasan & Medium & Perbaikan: memberikan lapisan tambahan (overlay) \\
\hline & III & Keriting & Medium & $\begin{array}{l}\text { Perbaikan: pada keriting yang dalam, dilakukan } \\
\text { penambalan pada seluruh kedalaman atau melakukan } \\
\text { rekonstruksi }\end{array}$ \\
\hline & & Retak Kulit Buaya & Low & $\begin{array}{l}\text { Pemeliharaan: melakukan penutupan permukaan atau } \\
\text { memberi lapisan tambahan (overlay) }\end{array}$ \\
\hline & & Retak Kulit Buaya & Medium & $\begin{array}{l}\text { Perbaikan: melakukan penambalan parsial atau seluruh } \\
\text { kedalaman atau dapat melakukan rekonstruksi pada } \\
\text { perkerasan }\end{array}$ \\
\hline \multirow[t]{4}{*}{8.} & $\begin{array}{l}\text { Jalan } \\
\text { Bintang }\end{array}$ & $\begin{array}{l}\text { Retak Berkelok - } \\
\text { Kelok }\end{array}$ & Low & Pemeliharaan: belum memerlukan pemeliharaan \\
\hline & Diponggo & Tambalan & Medium & $\begin{array}{l}\text { Perbaikan: melakukan pengisian pada celah retakan } \\
\text { dengan campuran aspal cair dan pasir dan dilapis dengan } \\
\text { lapisan agregat dengan gradasi seragam }\end{array}$ \\
\hline & & Alur & Medium & $\begin{array}{l}\text { Perbaikan: melakukan penambalan seluruh kedalaman } \\
\text { atau memberikan lapisan tambahan campuran aspal panas }\end{array}$ \\
\hline & & Pengelupasan & Low & Pemeliharaan: belum memerlukan pemeliharaan \\
\hline \multirow[t]{3}{*}{9.} & $\begin{array}{l}\text { Jalan } \\
\text { Dukuh }\end{array}$ & Retak Melintang & Medium & $\begin{array}{l}\text { Perbaikan: melakukan penambalan jika retakan diikuti } \\
\text { oleh jenis retak yang lain }\end{array}$ \\
\hline & $\begin{array}{l}\text { Kupang } \\
\text { Timur I }\end{array}$ & Retak Kulit Buaya & Medium & $\begin{array}{l}\text { Perbaikan: melakukan penambalan parsial atau seluruh } \\
\text { kedalaman atau dapat melakukan rekonstruksi pada } \\
\text { perkerasan }\end{array}$ \\
\hline & & Tambalan & Low & $\begin{array}{l}\text { Pemeliharaan: melakukan perawatan permukaan (surface } \\
\text { treatment) }\end{array}$ \\
\hline 10 & $\begin{array}{l}\text { Jalan } \\
\text { Dukuh }\end{array}$ & Amblas & High & $\begin{array}{l}\text { Perbaikan: area kerusakan besar, menambal permukaan } \\
\text { atau seluruh kedalaman }\end{array}$ \\
\hline
\end{tabular}




\begin{tabular}{|c|c|c|c|c|}
\hline No. & Lokasi & Jenis Kerusakan & $\begin{array}{c}\text { Tingkat } \\
\text { Kerusakan }\end{array}$ & Alternatif \\
\hline \multirow{8}{*}{11} & Kupang & Pelapukan dan & Medium & Perbaikan: melakukan rekonstruksi pada perkerasan \\
\hline & Timur X & Butiran Lepas & & \\
\hline & & Tambalan & Low & Pemeliharaan: belum memerrlukan pemeliharaan \\
\hline & & Pengelupasan & High & $\begin{array}{l}\text { Perbaikan: membersihkan lapisan permukaan dari bahan } \\
\text { yang menyebabkan lapisan permukaan menjadi aus }\end{array}$ \\
\hline & $\begin{array}{l}\text { Jalan } \\
\text { Dukuh }\end{array}$ & Retak melintang & Low & $\begin{array}{l}\text { Pemeliharaan: melakukan penutup pada retakan yang } \\
\text { mulai mengganggu kondisi jalan }\end{array}$ \\
\hline & $\begin{array}{l}\text { Kupang } \\
\text { XX }\end{array}$ & Alur & High & $\begin{array}{l}\text { Perbaikan: melakukan penambalan seluruh kedalaman } \\
\text { atau memberikan lapisan tambahan campuran aspal panas }\end{array}$ \\
\hline & & $\begin{array}{l}\text { Pelapukan dan } \\
\text { Butiran Lepas }\end{array}$ & High & Perbaikan: melakukan rekonstruksi pada perkerasan \\
\hline & & Lubang & Medium & Perbaikan: melakukan penambalan di seluruh kedalaman \\
\hline
\end{tabular}

Berdasarkan pada Tabel 4, pada kerusakan tingkat low dengan kondisi jalan yang sedang (fair), maka belum dipelukan pemeliharaan, sedangkan untuk tingkat low pada jalan dengan kondisi buruk (poor) atau sangat buruk (very poor) diperlukan pemeliharaan dan tingkat medium dan high diperlukan perbaikan berdasarkan jenis kerusakan.

\section{KESIMPULAN}

Berdasarkan pada hasil analisis dan keseluruhan pembahasan, maka kesimpulan yang diperoleh adalah:

1. Jenis kerusakan yang paling dominan pada jalan di wilayah Surabaya Selatan adalah kerusakan retak, serta tingkat kerusakan jalan bervariasi, mulai dari low, medium, dan high severity, dan terdapat jenis kerusakan yang berbeda pada titik yang sama.

2. Berdasarkan pengamatan langsung, persentase dan nilai kerusakan tertinggi pada Jalan Kembang Kuning dan Jalan Pakis Tirtosari III.

3. Berdasarkan pada nilai kerusakan jalan dengan metode PCI diperoleh pada Jalan Dukuh Kupang XX memiliki nilai kondisi terendah sebesar 25 (very poor).

4. Pada Jalan Kembang Kuning dan Jalan Pakis Tirtosari III dibutuhkan pekerjaan pemeliharaan, sedangkan pada Jalan Dukuh Kupang dibutuhkan perbaikan.

\section{UCAPAN TERIMAKASIH}

Penulis mengucapkan terima kasih kepada pihak- pihak bersangkutan telah membantu selama survei di lapangan.

\section{DAFTAR PUSTAKA}

Almuntsari, Daud. (2018) Evaluasi Tingkat Kerusakan Jalan Raya Puger Desa Menampu Kecamatan Jember Menggunakan Metode Dirgolaksono Dan Indrasurya B. Moctthar (STA 0+000 - 3+000) Digital Digital Repository Repository Universitas. Jurusan Teknik Sipil, Universitas Jember., 1(3), 1-56.

Canestrari, F., \& Ingrassia, L. P. (2020) A Review of Top-Down Cracking in Asphalt Pavements: Causes, Models, Experimental Tools and Future Challenges. Journal of Traffic and Transportation Engineering (English Edition), 7(5), 541-572.

Djalante, S. (2011) Evaluasi Kondisi dan Kerusakan Perkerasan Lentur di Beberapa Ruas Jalan Kota Kendari.

Hadid, M., Ubudiyah, A., \& Apriyani, D. W. (2020) Alternatif Aspal Modifikasi Polimer dengan Menggunakan Sampah Plastik Kemasan Makanan. Jurnal Manajemen Aset Infrastruktur \& Fasilitas, 4(1), 43-52.

Hardiyatmo H.C. (2015) Pemeliharaan Jalan Raya. Gajah Mada University Press, Yogyakarta.

Japan International Cooperation Agency (JICA) (2005) Teknik Pengelolaan Jalan. Badan Penelitian dan Pengembangan Pusat Penelitian Pengembangan Prasarana Transportasi, October 2013, 1-224

Jehadus, S. (2019) Analisis Faktor Penyebab Kerusakan Jalan Raya Lintas Labuan Bajo - Lembor Flores Nusa Tenggara Timur. 1-25.

Juwita, F., \& Ariadi, D. (2018) Analisis Jenis Kerusakan Perkerasan Lentur Menggunakan Metode Pavement Condition Index (Studi Kasus Jalan Ratu di Balau Bandar Lampung). Tapak, 8(1), 66-78.

Kementrian Pekerjaan Umum. (2007) Pedoman Teknis Pembangunan Gedung Negara. 1, 1-14. 
Keputusan Walikota Surabaya Nomor 46 Tahun 2000 tentang Kelas Jalan di Kota Surabaya.

Misaghi, S., Tirado, C., Nazarian, S., \& Carrasco, C. (2021) Impact of Pavement Roughness and Suspension Systems on Vehicle Dynamic Loads on Flexible Pavements. Transportation Engineering.

Misbah, M., \& Edrizal, E. (2016) Studi Analisis Tingkat Kerusakan dan Alternatif Perbaikan Jalan Kota Ruas Gunung Sarik Kota Padang Sta 0+000 s/d 1+000. Jurnal Momentum, 18(2), 26-34.

Mubarak, H. (2016) Analisa Tingkat Kerusakan Perkerasan Jalan Dengan Metode Pavement Condition Index (PCI) Studi Kasus: Jalan Soekarno Hatta Sta. 11 + 150. Jurnal Saintis, 16(1), 94-109.

Nugroho, E. A. (2013) Pengaruh Jumlah Kendaraan terhadap Kerusakan Jalan Aspal Kelas II di Kabupaten Semarang. Jurusan Teknik Sipil, Fakultas Teknik, Universitas Negeri Semarang.

Pinatt, J. M., Chicati, M. L., Ildefonso, J. S., \& Filetti, C. R. G. D. arc. (2020) Evaluation of Pavement Condition Index by Different Methods: Case Study of Maringá, Brazil. Transportation Research Interdisciplinary Perspectives, 4, 100100.

Shah, Y. U., Jain, S. S., Tiwari, D., \& Jain, M. K. (2013) Development of Overall Pavement Condition Index for Urban Road Network. Procedia - Social and Behavioral Sciences, 104, 332-341.

Singh, A. P., Sharma, A., Mishra, R., Wagle, M., \& Sarkar, A. K. (2018) Pavement Condition Assessment Using Soft Computing Techniques. International Journal of Pavement Research and Technology, 11(6), 564-581.

Sukirman, S. (1992) Perkerasan Lentur Jalan Raya, Nova, Bandung.

Suswandi, A., Sartono, W., \& Christady H, H. (2008) Evaluasi Tingkat Kerusakan Jalan dengan Metode Pavement Condition Index (PCI) untuk Menunjang Pengambilan Keputusan (Studi Kasus: Jalan Lingkar Selatan, Yogyakarta). Civil Engineering Forum Teknik Sipil, 18(3), 934-946-946.

Undang - Undang Repuplik Indonesia Nomor 38 Tahun 2004 tentang Jalan.

Widayanti, A., Wibisono, R. E., \& Sari, C. K. (2020) Tipe Kerusakan Jalan Provinsi dan Penentuan Skala Prioritas Penanganan di Kabupaten Lamongan. Type of Damage of Provincial Roads and Determination of Priority Scale for Handling in Lamongan Regency. 2 (2).

Yang, Q \& Zhou, S. (2020) Theoretical Analysis of Pavement Deflection Response Sensitivity Under Steady-State Excitation. International Journal of Transportation Science and Technology.

Widayanti, A., Soemitro, R. A. A., Ekaputri, J. J., \& Suprayitno, H. (2020) Analisis Pemanfaatan Zat Aditif pada Reclaimed Asphalt Pavement untuk Lapisan Beton Aspal. Jurnal Manajemen Aset Infrastruktur \& Fasilitas, 4(1).

Widayanti, A., Soemitro, R. A. A., Eka Putri, J. J., \& Suprayitno, H. (2017) Karakteristik Material Pembentuk Reclaimed Asphalt dari Jalan Nasional di Provinsi Jawa Timur. Jurnal Manajemen Aset Infrastruktur \& Fasilitas, 1(1), 11-22. 